\title{
INTERNATIONAL JOURNAL OF INNOVATIVE SCIENCE AND RESEARCH TECHNOLOGY
}

\section{IJISRT ADIGITAL LIBRARY}

ISSN NO :- 2456-2165

\section{AUTHOR CERTIFICATE}

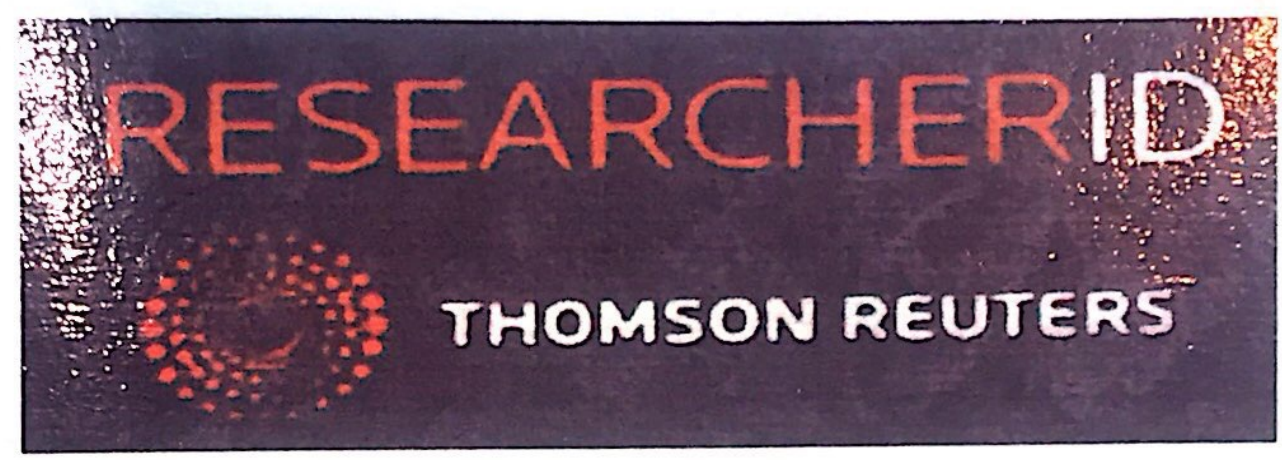

HAS BEEN PUBLISHED IN

Volume 3| Issue 9| September - 2018

ARTICLE DIGITAL NO.

IJISRT18SP198

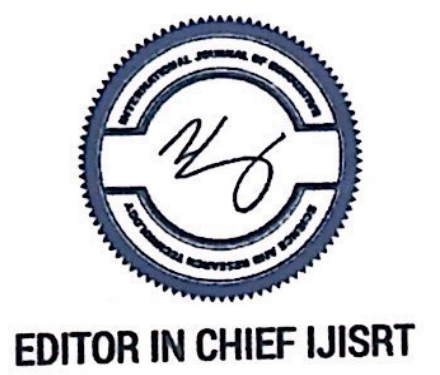

This document certifies that the manuscript listed above was submitted by above said respected author To verify the submitted manuscript please visit our official website: www.ijisrt.com Or Email us: editor@ijist.com 


\section{INTERNATIONAL JOURNAL OF INNOVATIVE SCIENCE AND RESEARCH TECHNOLOGY}

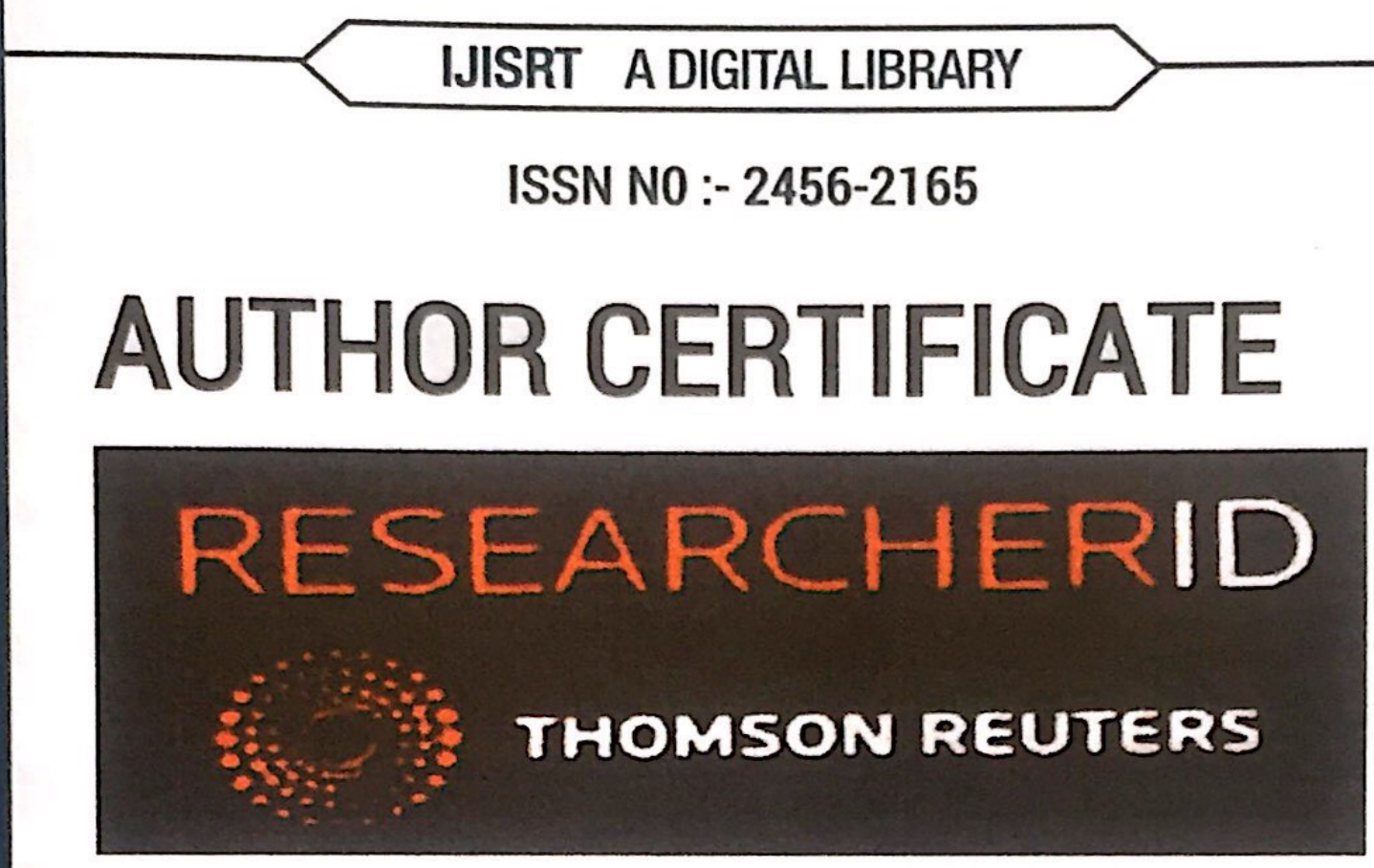

HAS BEEN PUBLISHED IN

Volume 3| Issue 9| September - 2018

ARTICLE DIGITAL NO.

IJISRT18SP198

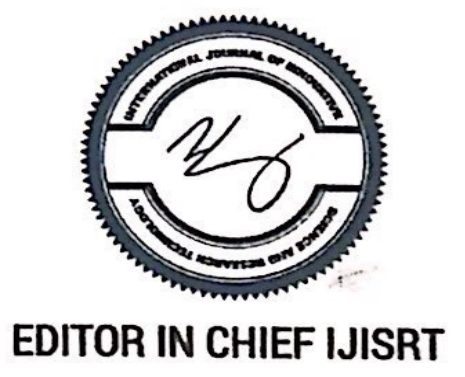

This document certifies that the manuscript listed above was submitted by above said respected author To verify the submitted manuscript please visit our official website: www.ijisrt.com Or Email us: editor@ijisrt.com 


\section{Table of Contents}

1. The Role of Perceived Trust on Consumer Intention Toward Mobile Banking in Palestine

Haitham M Jouda \& Valliappan Raju

2. A Survey about Women's Personal Hygiene and Safety Measurements and its Impact on Nature

S.Deepapriya \& N.Manjula Devi

3. Total Quality Management Factors in Bahrain Higher Education Institutions:

Influences on their Performance

Zahra Merza Moosa Ahmed

4. Allelopathic Effects of Adhatoda Vasica and Eupatorium Adenophorum on Germination and Growth Behavior of Capsicum Annum

S. Chimouriya, / I. Shrestha, S. Piya, / J.Lamichhane, / D. Gauchan

5. Development Strategies of Tourism-Based Economic Independence in Indonesia

Dr Eli Hasmin SE, MM, / Dr Patta Rapanna SE, M.Si / Yudi Akhmad Sadeli, SE, M.Fin

6. Study of Diesel Engine Performance and Emission Trend Fuelled with BiodieselDiesel Blends

Akash Paul Lecturer / Amiya Bhaumik, / Kushal Burman, 


\section{Development Strategies of Tourism-Based Economic Independence in Indonesia}

\author{
Dr Eli Hasmin SE, MM \\ (Lecturer in Macassar college of \\ economics (STIEM Bongaya). \\ the city of Makassar, South Sulawesi \\ Province, Indonesia
}

\author{
Dr Patta Rapanna SE, M.Si \\ (Lecturer in Macassar college of \\ Economics ( STIEM Bongaya)
}

\author{
Yudi Akhmad Sadeli, SE, M.Fin \\ (Lecturer in Macassar college of \\ Economics ( STIEM Bongaya )
}

\begin{abstract}
This type of qualitative research approach through Phenomenology, as results showed that the tourism sector is an important sector in stimulating the economic development of both the macro level as well as the micro level, the success of tourism vary Depending on the seriousness of the Government and the support of the whole party is either an element of Government, private, community and among educators, in addition to that aspect of the management of the leading resource-based and reliable promotion will accelerate success tourism in Indonesia
\end{abstract}

Keywords:- Tourism stakeholders, strategies, service, construction.

\section{INTRODUCTION}

The community is a group of people who are in the same geographic area and make use of local natural resources existing in the vicinity. In developed and developing countries in general tourism managed by private circles that have large venture capital from outside the region and even outside the country. So local communities residing in an area of tourism destinations could not be directly involved in tourism activities.

The lack of participation of local communities in tourism activities often give rise to the opinion that the local communities instead of including stakeholders from tourism and are a marginal group of business opportunities in the field of tourism.

Basically the local communities have the knowledge about the natural and cultural phenomena that exist in the vicinity. But they do not have the ability to be financially qualified and expertise to manage it or was directly involved in tourism activities based on nature and culture. Since the last few years, the potential-potential that is owned by the local community used by the managers of protected areas (protected area) and tourism entrepreneurs are to be included in the safeguard of nature and sustainability biodiversity existing in its territory.

Local communities should be actively involved in the development of tourism. Further, tourism is also expected to provide opportunities and access to local communities to develop the supporting business such as tourism; craft shops, souvenir shops, food stalls and other local communities in order to gain more economic benefits and directly from travelers who used to enhance welfare and the extent of his life.

The level of community involvement in tourism is very different and this depends on the type of potential, experience, knowledge and expertise possessed by individuals or local communities. Local tourism is the tourism potential that owned each area, either in the form of nature tourism, cultural tourism nor tourist. This indicates that each area has a variety of local tourism potential that will be excavated, processed, managed and developed to meet the needs of society against the means of entertainment or recreation. One of the places that can be used to meet the demands of the community is a place for recreation or tourist attractions though the only form of recreation or tourist attractions, local scale only prioritized to meet the demands of the community in the area as well as communities in the surrounding area.

Starting from the condition that the local tourism development in addition to meet the needs of society against the means of entertainment or recreation can also provide several advantages both economically and for economic development area. It can be known from increasing people's income levels surrounding the tourist attractions of recreational activities as well as a growing tourism on its territory. From recreational activities as well as the growing tourism community around the recreation area can open business opportunities by providing a variety of services as well as services to meet the needs of travelers. So with the venture will automatically raise the level of well-being of citizens around the locations for recreation or tourism.

Discuss about the role of Government in tourism is very familiar for our lives. The role of Governments is crucial especially in protecting tourists and enrich the experience of the journey or heightens. The role of the regulation or regulations that are essential to be made the Government for the benefit of the Regulation is the protection of tourists especially for tour operator that require traveler to pay a deposit (deposit payment) as guarantee booking services such as accommodation, tour and other - other, fire safety regulation which covers the settings with the minimum number of lights that there in each floor of the hotel and other security support tools, food and health safety regulation 
governing health food that is presented to the tourist, the standard rules of competence of workers - workers who need special knowledge and expertise as a pilot, driver and nahkoda.

In addition, the Government is also responsible for the management of natural resources such as; Rare flora and Fauna, water land and also air pollution occurs in order to not be intrusive even damage an ecosystem. Therefore, the implementation of all government regulations and laws absolute law implemented by the Government. In the development of tourism should be a development of the planning thoroughly, so that it can be benefits that is optimal for the community, both in terms of the economy. Social and cultural. The planning should integrate the development of tourism into a program of economic development, physical, and social of a country. In addition, the plan must be able to provide the framework of Government policy, to encourage and control tourism development. The role of Government in developing tourism in the outline is to provide infrastructure (not only physical form), expanding the range of facilities, activities coordination among government agencies with tours, arrangements and promotion General out of the country. Cannot be denied that almost throughout the region of Indonesia, there is the potential of tourism, so that attention is the suggestion, the State transportation infrastructure and means - means tourism.

\section{FORMULATION OF THE PROBLEM}

- How the development of tourism in Indonesia.

\section{A REVIEW OF THE LITERATURE}

\section{A. Marketing}

In defining the marketing we can distinguish between social and managerial definition for marketing. According to the definition of social marketing is a social process by which individuals and groups obtain what they need and want through the creation, offering, and exchanging products and services of value with others (Philip Kotler, 2002). As the definition of managerial, marketing is often described as "the art of selling a product". "But Peter Drucker, a leading management theorists, saying that" the goal of marketing is to make selling superfluous. The goal of marketing is to know and understand the customer so well that the product or service fits him and sells itself (Philip Kotler, 2002).

Marketing is the management process for identifying, anticipating and satisfying customer requirements profitably. Marketing is the process of planning and executing the conception, pricing, promotion and distribution of ideas, goods and services to create exchanges that satisfy individual and organizational objectives. Both these definitions reflect the view of traditional transaction-oriented marketing. They do not contain an explicit recognition of the long-term value of a customer. The theory has begun to develop an alternative definition that captures the nature of the new marketing.
Gronroos (1990, 1991; 1994, p355 in Francis Butle, 1996), for example, offers the following: "Marketing is to build, maintain, and enhance relationships with customers, and other partners, at a profit, so that the goal of the parties involved are met.

A case study related to marketing in the form of dependency relationship, trust, commitment, communication, cooperation, and equity. Researchers in marketing has a well established tradition of dependency checking in consumer relations-seller. On the work of Emerson (1962) and Beier and Stern (1969), Frazier (1983) in the Jeffrey e. Lewin and Wesley j. Johnston (1997) proposes that the dependence of the buyer on the seller directly related to consumers ' needs to maintain the relationship in order to achieve the desired goals (e.g., profit, sources of supply, customer service).

Heide and John (1988) in the Jeffrey e. Lewin and Wesley j. Johnston (1997), identified four situations in which the buyer's reliance on suppliers is increasing: (1) when the results obtained from the buyer-consumer relations are important, highly valued, and/ or the magnitude of the Exchange are high, (2) when the relationship affords consumers the benefits of relatively better compared to the benefits available from alternative relationships, (3) when several potential sources of available Exchange alternatives, and (4) when considered either difficult or expensive to replace the incumbent supplier.

Formal marketing studies focusing initially on the distribution and exchange of commodities and manufactured products and displays a foundation in the field of Economics (Marshall, 1927; Shaw 1912; In 1904, Smith Stephen 1. Vargo and Robert f. Lusch, 2004). Originally Bachelor marketing direct their attention towards commodities exchange (Copeland 1920 in Stephen 1. Vargo and Robert f. Lusch, 2004), the Institute of marketing that make goods available and arranged for ownership (Nyström 1915; Weld in 1916 Stephen 1. Vargo and Robert f. Lusch, 2004), and the functions that needed to be made to facilitate the exchange of goods through marketing (Cherington 1920; Weld 1917 in Stephen 1. Vargo and Robert f. Lusch, 2004).

We need to leave the display opaque on marketing and sales as an isolated phenomenon and well defined. We need to expand marketing and sales management for public and social life, even life itself. There are many definitions of marketing relations, most of them emphasize the development and maintenance of long term relationships with customers and sometimes with the other stakeholders (Christopher, Payne and Ballantyne 1991; Morgan and Hunt 1994; Gronroos 1997, 2000 in Jagadish n. Sheth and Parvatiyar Atul, 2002). My definition of a broader relationship marketing by systemic and look into relationship marketing management in a comprehensive and social context (Gummesson, 1999, p. 24 in Jagadish n. Sheth and Parvatiyar Atul, 2002): the amount of relationship marketing is marketing based on relationships, networking and interaction, recognise marketing embedded in 
the management of total sales network organization, market and society.

According to Kotler (1991) as quoted by Eid and Trueman (2002:56), the promotion is the various ways your organization to communicate the excellence of its products and convince consumers to buy their products. Use of advertising via the internet and developing sales promotions that smart is a good concern, but other promotional media also changed (Peattie, 1997:148).

The effect of internet use on promotional strategies for the company appeared in many studies as Avlonitis and Karayanni, 2000; Bennet, 1997; Hamill, 1997a, b; POON and Jevons, 1997; Quelch and Klein, 1996; Wilson and Abel, 2002 (Eid and Trueman, 2002:57). For the Sales Department, using the internet have interactive communication with consumers. According to Poon and Jevons (1997:30), sales of which have to be extra hard (hard-selling) and promotion strategy should encourage the stimulus (advertiser-push) for consumers do not have to do with internet media. The Internet can also reduce the cost of advertising (advertising) global so that it becomes cheaper (Hamill, 1997:310).

However, Wilson and Abel (2002) suggests that many online promotion techniques done turns in it also there is still such an offline promotion techniques form the traditional advertising that is word of mouth (mouth by mouth). According to Bennett (1997:325), advertising on the web pages it is possible but it is not accepted either because consumers sometimes expect the real shape of the product.

\section{B. Tourism}

Lundberg (1997), describing the term tourism or tourism are people who travel away from home, and the companies that serve by way of expedited or facilitate their journey, or make it more fun. As a concept, tourism can be reviewed from a variety of different facets. Tourism can be seen as an activity to travel home with the intention of not doing business, or just a relaxing activity, (McIntosh and Goeldner, 1986 in Hatane Semuel, 2007).

Tourism consumers known as tourists. The World Tourism Organization, the World Tourism Organization (WTO), defines tourism (tourism) as "the activities of the person traveling to and staying in places outside their usual environment for not more than one consecutive year for leisure, business and other purposes ".

While Jafar Jafari defines as: "is a composite of activities, services, and industries that delivers a travel experience, namely, transportation, accommodation, eating and drinking establishment, shop, entertainment, facilities, and activity other hospitality services available for individual or groups that are traveling away from home. It encompasses all providers of visitor and visitor-related services ".
Tourism according to Robert McIntosh along Shaskinant Gupta in Oka, a. Yoeti (1992:8) is a combination of symptoms and the relationships that arise from the interaction of tourists, business, Government and society hosts a host in the process attract and serve the tourists-tourists and other visitors.

According to Richard Sihite in Marpaung and Bahar explained the definition of tourism as follows: tourism is a journey that people do it for a while, which was held from a place to another leaving a place again, with a planning and with the intent not to seek or make a living in the places visited, but simply to enjoy sightseeing and recreational activities or to satisfy the desires of a diverse.

According to a broader definition advanced by $h$. Kodhyat (1983:4) is as follows: tourism is traveling from one place to another, are temporary, individual and group, conducted as a business looking for a balance or harmony and happiness with the environment dimension in the social, cultural, nature and science. While the opinion of James $\mathrm{j}$. Spillane argued that tourism is an activity to travel with the aim of getting pleasure, looking for satisfaction, knowing something, improve health, enjoy sports or break, perform the task, make a pilgrimage and others.

According to the Wrong definition of tourism that is posited Wahab tourism is one of the new industry that is able to accelerate the economic growth and the provision of employment opportunities, increased income, living standards and stimulate sectors other productive. Furthermore, as a complex, tourism sector also effort to industries such as industrial handicrafts and souvenirs, lodging and transportation.

While the notion of tourism according to the Act No. 9 of the year 1990 in chapter I, article 1, that Tourism is anything related to the Organization of tourism. This means that all the activities and Affairs of that has to do with planning, arrangement, execution, supervision, good tourism undertaken by Government, private parties and society called Tourism.

\section{The role of the Community}

Well as a process that involves the public, known as the role of the community. That is the process of two-way communication that goes on constantly to increase the sense of community in full over a process activity, where the problems and needs of the environment are being analyzed by the authoritative bodies. Simply Canter defines as a feed-forward information (communication from the Government to the public about a policy) and feedback information (communication from the community to the Government of the policies).

From the role of terminology as well as community can be interpreted as a way of conducting the interaction between the two groups; The group that had not included in the decision-making process (non-elite) and groups that perform 
decision making (elite). Discussion of the more specifically, the role of the community is indeed a way to discuss the material they need incentive (Goulet, 1989). In other words, the role of society is the moral incentives as a "Passport" to influence macro-scope higher, where he made a very decisions determine their well-being.

Cormick distinguishes the role of the community in the decision-making process by virtue of its nature, namely the consultative in nature and the nature of partnerships. In the role as well as the community consultative relationship patterns among party officials decision makers with community groups of interested parties, the members of the society have the right to be heard and to be told his opinion, where the final decision remains in the hands of officials of the decision maker. Being in the context of the role of the nonprofit community partnership, the official decision makers and members of the community is relatively parallel partners its position. They together discuss, looking for an alternative problem solving and discuss decisions. that is a lot of still looks at the role of the community solely as delivery information (public information), counseling, even the mere public relation tool so that the project can proceed without a hitch. Therefore, the role of the community is not only used as a means to achieve the goal, but it is also used as a destination (participation is an end itself).

In this current era of globalization, where the public can access all information quickly and they can interact with anyone, anytime and anywhere. As there is no longer a country's territorial limits, as they already can easily find out the situation and conditions outside the country. The public is presented with a variety of reality which aspects influenced a scene. This means that we know the motives of any event on this earth there is always a reason that is in line with the events. This led to criticism of the community become more honed. Now, with globalization, we cannot look at anything with just black and white paradigm relied on Incorrect or correct. There are a variety of considerations that requires us to think deeper and assess things. One of the many considerations that are looking at the necessity to unify the principles of democracy and bureaucracy.

Democracy as one of the possible foreign in the ear to understand our community, has now become a meal should be presented every day in the Association governance. So did the Government system (bureaucracy) could not be closed again from the democracy that is being loved by the community.

The era of openness of the Administration against the values of democracy are still belongs to the young, but advances in it was very surprising. If from the point of view of Indonesia, starting from the reform of 1998 with Suharto as a symbol his otoritarianesme stepped down until the abolition of the dual function of ABRI and the last one is the presidential election directly.
The success of reform became an important record of the presence of momentum the unification of spirit of democracy and bureaucracy. The issue as to whether the unification of sprit that can take place while the democracy and bureaucracy have essentially different principles. And as to whether the process of assimilation between democracy and bureaucracy in an era of openness today. In addition it must be such as to whether Government officials being responded to infiltrate his democratic values into the bureaucracy.

\section{RESEARCH METHODS}

Qualitative research approach through kind of Phenomenology

\section{DISCUSSION}

Tourism as a product and a process. It should be understood that tourism as a product refers to all forms of tourism activities and services that directly provide economic value as a commodity. While the significance of tourism as a development refers to the process of human behavior in the developing and inherited values of tourism that exists, whether actual or potential, tangible and intagible. Surely it is aiming to develop the endurance and quality of life of human beings in their environment. It is obvious this becomes a unit where a set of activities and Tourism Ministry prepared and launched to the public worth became a vehicle for human awareness will meaning himself and his environment. Of course related to the education of tourism need to be prepared for professional resources, which has a strategy to make the tourist destinations that have a value of adaptation and survival of the value of heritage and tourism.

Tourism as a sector that is expected to give the welfare society must be put in a position to construct quality life skills, foster emotional life, spiritual, ethical and healthy, as well as foster business resources and financial braid sustainability of human life in a social networking space. Moreover, tourism in Indonesia currently occupies a strategic position, even in the year 2013, the tourism sector occupy the No. 4 in the acquisition of foreign exchange, after oil and gas, palm oil and rubber oil The emphasis is important for sustainable tourism development is the need to build a living local values that have the power of adaptation to global life. Because of its cultural diversity and potential of the nation on the one hand and global competitiveness should be built on the other. All have to be rooted to the strength and uniqueness of locally developed within the framework of thought competition (based on local advantages. This is in harmony with the development of responsible tourism in the Global Code of Ethics for Tourism.

Prospects in tourism sector into a loophole for Indonesia to pursue failed with neighboring countries such as Malaysia, Singapore and Thailand. Until the year 2019, President Jokowi has set a target for tourism rose to double that. 
Contribution to gross domestic product (GDP) of around $8 \%$ nationwide, to foreign exchange earnings i.e. $\mathrm{Rp} 240$ trillion, the amount for the visit of wisman 20 million and 275 million archipelago tourist movement. In addition to this index in the competitiveness of tourism in the ranks of the world's 30 .

To build a winning tourism then it is the task of the entire tourism stakeholders in preparing human resources professional, competitive, ethical and empowered to develop tourism. Specialized HUMAN RESOURCES of tourism consisting of community, labor and tourism professions, Labor candidate who attended tourism. Education in community settings as non formal education needed to cultivate awareness and public participation in the development of sustainable tourism. Professional graduate school of tourism Tourism HUMAN RESOURCES needed to develop competent and empowered global competitiveness. As for the educational development of prospective workforce prepared to educate prospective labor in order to have competence, competitiveness, and ethics in developing tourism. Related in terms of the clear strategic role UPI in advancing education in formal and non-formal sectors related with the development of tourism. " Ultimate exposure Sunaryo (Dewi Turgarini)

The community is one of the main pillars in the development of tourism, because tourism is the pillar that basically consists of the first Government, both the private and the third community, often called the three main pillars of tourism. For example, after the Government issued a policy on the development of tourism which is accompanied by regulation of course. Then the private companies that provide services professionally for tourism development, the task of the community is in addition to the always evokes an awareness of the importance of tourism also cultivate creativity that spawned a variety of fresh creations that invites attention to later become the allure of tourism.

Regarding development or tourism awareness among the public this is not an easy thing. Although the existence of sociological society in Indonesia has become a real attraction for tourism, both with a wealth of customs and traditions, art creations in various facets of his life also treasure the environment and history relatively rich enough and become the pride of the world.

The hope that creation of which cultivate is located at: first, there is still a stigma that tourism can affect the lives of the less well or badly will effect on the process of the formation of a moral society. As we know, that through tourism occurs the process of acculturation which is indeed well behind it all many provide added value.

Second, it is still the existence of an excessive attitude towards tourists especially wisman (foreign tourists), either from the side or from the security side of health care. So that excessive precautions may result in less conducive for the tourists when they visit a tourist attraction.
Third, yet the growing attitude of society to protect and provide services to tourists at least with congratulate and give a smile still happens so that the incidents inconvenience in various areas that are becoming tourist attractions.

Fourth, yet the formation of attitudes and viewpoints that tourism, like many proven in various countries, promising also for the realization of a prosperous society.

Four of these are indeed can be reduced, if not lost altogether, due to the process of synergy between Government, the private and the public, for example, indicate a strong commitment from the Government to be earnest build tourism by itself will be spontaneity appeared also the participation of the community. From here itself will be born and develop creative tourism as a form of community participation, and also as a form of its commitment. Moreover, if the society then has woken up a view that tourism is one of the sectors of the economy which can bring in foreign countries, increase revenue and income. So that tourism can be seen as a sector that was able to realize a welfare society.

\section{A. Issues Are Conveniently Located}

Strategic issues related to the tourism sector in the RPJMN 2015-2019 amongst others; The potential of natural beauty and unique cultural diversity was the capital for the development of national tourism. The potential of natural beauty and unique cultural diversity was the capital for the development of national tourism. Tourism development goals in 2015-2019 is divided into RPJMN target growth and inclusive development goals.

Whereas in the inclusive development goals is Increasing the local businesses in the tourism industry and the increasing number of local workforce certified

D Direction of tourism development policy outlined in RIPPARNAS, namely

- Development of Tourism Destinations geared to enhance the attractiveness of tourist destination so that competitive power in the country and abroad, with strategy; (1) facilitating the development of national tourism destinations that become focus: (a) nature tours consist of a adventure tours, nautical tourism and ecological tourism; (b) cultural tourism which consists of tourism heritage and religion, culinary and shopping, and tours of towns and villages; and (c) artificial tourism and special interest tours that consist of Meeting Incentive Conference and Exhibition (MICE) events, sports tourism \&, and tour the area integrated; (2) improve the image of the tourism and the movement of tourists archipelago; (3) the governance of Destinations; and (4) community empowerment in tourism destinations. This type of tourism will be developed especially for overseas travelers include: (a) natural attractions which consists of tourism nautical tourism, ecological, and adventure tourism; (b) cultural tourism which consists of tourism heritage and religion, culinary and shopping, and tours of towns and villages; and 
(c) the creation of tourism tour consists of MICE tourism Event, sports \&, fitness tour (wellness)-based culture of the archipelago, as well as tours of the area.

- National Tourism Marketing is directed to increase international cooperation in tourism and bring foreign tourists visit as much as possible,

- Development of the tourism industry are directed to increasing participation of local venture in the national tourism industry and to improve the diversity and competitiveness of the national tourist product/service every destination the tourism became the focus marketing through: (a) fostering business tourism for local communities; (b) facilitation of business tourism sector investments; and (c) the development of standards and certification efforts and tourism product; and (d) the development of ecosystem tourism industry integration.

- Institutional Development of tourism is directed to wake up human resources of tourism as well as the Organization of a national tourism strategy: (a) coordinate with the college education providers in Tourism; (b) increase the capacity and quality of vocational education of tourism; (c) facilitation level of development and improvement of skills of the local workforce in tourism; (d) improvement of the quality of research and policy development of tourism; and (e) manage and control change management.

\section{B. Indonesia's Tourism Sector's Potential}

The tourism sector is one of the leading sectors that have potential and great contribution on Indonesia's economy. Based on the results of the identification data of the Ministry of tourism and Creative Economy and BPS, the number of tourists who do tour in Indonesia from both within and outside the country increased every year. It is also supported by Ministry of tourism data and creative economy years 2013 about foreign countries who mention that the tourism sector in Indonesia occupies the fourth position in the type of commodity foreign exchange earner after Oil and most gas Earth, coal, and oil palm. This proves that the tourism sector is an important sector in the economy of Indonesia. Here is the complete table ranking foreign tourism in 2009-2013.

\begin{tabular}{|c|c|c|c|c|c|c|c|c|c|c|}
\hline \multicolumn{11}{|c|}{ RANKING DEVISA PARIIIISATA TAHUN $2009 \cdot 2013$} \\
\hline \multirow[b]{2}{*}{$\mathrm{mat}$} & \multicolumn{2}{|l|}{$m$} & \multicolumn{2}{|l|}{2010} & \multicolumn{2}{|l|}{ IIII } & \multicolumn{2}{|l|}{2012} & \multicolumn{2}{|l|}{213} \\
\hline & vasilondilas & 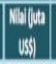 & Jabilinondths & 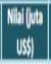 & Inilkondtas & 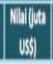 & mistlonallas & 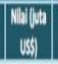 & Inistandilas & 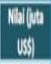 \\
\hline 11 & Mnastequburi & \multicolumn{2}{|c|}{ 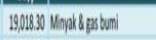 } & \multicolumn{2}{|c|}{ 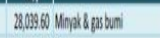 } & \multicolumn{2}{|c|}{ 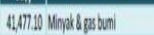 } & \multicolumn{2}{|c|}{ 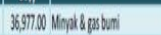 } & 326332 \\
\hline 21 & Batubn & \multicolumn{2}{|c|}{ 1381730 ctwoban } & \multicolumn{2}{|c|}{ 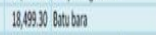 } & \multicolumn{2}{|c|}{27221200 axwbron } & \multicolumn{2}{|c|}{26.16330 botobon } & 25004 \\
\hline & Mrpokelesprant & \multicolumn{2}{|c|}{ 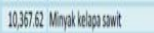 } & \multicolumn{2}{|c|}{ 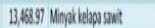 } & \multicolumn{2}{|c|}{ 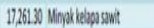 } & \multicolumn{2}{|c|}{ 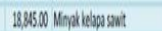 } & 15891 \\
\hline 41 & Privesth & \multicolumn{2}{|c|}{ 6,280,0 Guetdibn } & \multicolumn{2}{|c|}{ 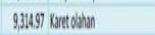 } & \multicolumn{2}{|c|}{ 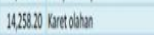 } & \multicolumn{2}{|c|}{ 103:3550 Priksth } & $10,05 \mathrm{SL}$ \\
\hline \& & Patianjod & \multicolumn{2}{|c|}{ 5,73560 Priwisth } & \multicolumn{2}{|c|}{ 1,02025 Painsoth } & \multicolumn{2}{|c|}{ 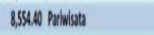 } & \multicolumn{2}{|c|}{ 9,1200ss Gertodhen } & 93366 \\
\hline $6 x$ & Wertolinen & \multicolumn{2}{|c|}{4870.68 palano jad } & \multicolumn{2}{|c|}{ 65sall Pobinjad } & \multicolumn{2}{|c|}{ 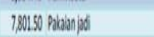 } & \multicolumn{2}{|c|}{ 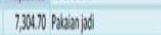 } & 150010 \\
\hline 11 & Atritiatir & \multicolumn{2}{|c|}{ 450.18 Aatistoth } & \multicolumn{2}{|c|}{ 6.33750 Astisotik } & \multicolumn{2}{|c|}{ 1360.30 Autistik } & \multicolumn{2}{|c|}{ 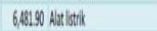 } & 64866 \\
\hline 8 & Tetast & \multicolumn{2}{|c|}{360218 Testil } & 47277 & & 556300 & & $528810 \mathrm{~N}$ & thenotionen & Sa48 \\
\hline 91 & Ketas ten bronget ictoss & 3,405011 I & 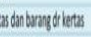 & 42419 & Jumndhn & 402201 & basmodetun & $5.13560 \mathrm{te}$ & & 52936 \\
\hline 101 & Mbennodban & 2500731 & amadumn & 36006 & Mulania & 46500 & ens don brongerienss & $3920 \mathrm{KK}$ & 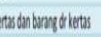 & 3022 \\
\hline 11 & Kawdethn & 2275338 & mking & 3,32185 & tas an bosnequetietas & 42340 & than lini & $363630 \mathrm{~K}$ & Woobinn & $3,5,45$ \\
\hline 12 & Baminana & $215541 \mathrm{~K}$ & volbon & 28049 & wodken & 328800 & wodition & $3337.70 \mathrm{~B}$ & the ining & 35016 \\
\hline
\end{tabular}

Source: Ministry of tourism and the creative economy, 2015
On the scope of the global tourism Indonesia ranks 74 higher from Cambodia, the Philippines and Viet Nam which is a neighboring country and incorporated in the ASEAN. Indonesia in the world tourism rankings compared to Southeast Asian. The potential of the tourism sector in Indonesia is certainly not small. According to the UNESCO in the year 2012, Indonesia have the correct four tourist sites that bore the title of UNESCO Natural World Heritage Sites. To four locations include Komodo National Park, Lorentz National Park, the tropical forests of Sumatra and Ujung Kulon. Compared to other Southeast Asian countries, Indonesia has the most. Malaysia, the Philippines, Thailand, and Viet Nam respectively have only two tourist sites. With the potential of the existing course targets the growing number of tourists who stated in the RPJMN 2015-2019 surely can be maximized with a variety of programs and development strategies. The tourism sector is also a potential sector-related jobs.

There are two main issues to consider in the development of tourism efforts of Indonesia, namely infrastructure development and capacity building of human resources. Until now, the development of human resources capacity is still low in view of the number of vocational school of tourism and hospitality, as well as informal tourism schools are still few in number.

Bank Indonesia together with the Central Government and local governments perform coordination of policy in an attempt to accelerate the improvement of the competitiveness of the industrial sector and tourism.

Strengthening the industrial and tourism sectors have an important role in realizing economic resilience, so that Indonesia's economy was able to grow higher, sustainable and inclusive, in the middle of the dynamics of external economy continued. Coordination meeting held on November 13 with 2015 in Yogyakarta was attended by the Governor and all the members of the Board of Governors of BI, Industry MinisterSalih Husin, Minister of public works and Housing-m. Basoeki Hadimoeljono, Minister of Agrarian and Spatial-Ferry Mursyidan Baldan, as well as the officials of the Ministry of tourism, Ministry of transportation, and the Ministry of STATE-OWNED ENTERPRISES. Meanwhile, the local Government of the present Governor of Daerah Istimewa Yogyakarta-Sri Sultan Hamengku Buwono $\mathrm{X}$ and Vice Governor of Jakarta-Djarot Saiful Hidayat, Deputy Governor of Central Java-Heru Sudjatmoko, as well as local government district/ cities in Yogyakarta and surrounding areas.

Strengthening the industrial and tourism sectors are directed to address a number of challenges. Facing the development of declining commodity prices and a weakening world demand, Indonesia's economic growth is no longer able to rely on the export of primary commodities. On the other hand, the industrial sector, which is one of the leading valueadded sectors and powerless labor high absorbency, have declining performance. It was reflected in the share of the 
industrial sector in GDP and the share of the industrial sector which exports decline. The decrease in performance is in line with the weakening of the competitiveness of the industry, particularly the industrial medium \& high tech, amid increasing global competition. This, among other things, caused a number of structural problems still posited, including logistical infrastructure. On the other hand, the development of the potential of the tourism sector, with a wealth of natural and cultural importance, it is still constrained by problems of infrastructure, especially transport.

Various efforts have been undertaken by the Government to enhance the competitiveness of the industrial sector and tourism. A number of policies, as part of a series of Government Policy Package I s/d VI, directed to support the competitiveness of national industries, among others, include efforts to encourage national industrial competitiveness through deregulation and bereaucracy, simplify investment licensing and the granting of tax incentives for transport, and land permits simplification. In the meantime, in order to improve tourism, several strategic measures that have been undertaken include Government policy on visit visa exemption into a total 90 countries, ease foreign tourists entered Indonesia to use the yacht (the ship), and accelerate the development of the infrastructure of airports and seaports.

\section{Industrial development was strengthened through increased competitiveness strategy amid increasing global competition.}

The strategy of increasing the competitiveness of the Industry Ministry was focused on strengthening the industrial structure policy, market access and the quality of the workforce. In addition, the development of the industry as a whole continues to be done by referring to the roadmap to achieve a strong, national industry competitive power, as well as innovation and technology-based. The implementation of the roadmap continues to be done on a consistent basis, including through a series of economic policy package.

Ministry of tourism continues to develop the tourism potential of Indonesia through deregulation and strengthening of tourism branding, as well as the determination of priority tourist destinations.

In addition to the associated economic policy package is deregulation of tourism which have been conducted, the Government continues to strengthen Tourism the Ministry of tourism branding Indonesia which showed a position the better among Asian countries. In addition, the Government has established 10 priority tourist destinations accompanied by a development roadmap to the future.

Industrial development and tourism has become a concern of the general policy of the Ministry of public works and Housing (PUPR). This is done in the form of infrastructure development that supports the development of industry and tourism. Construction of roads to improve access to tourism and industrial centers continue to be improved. In addition, the Ministry of PUPR seeks to improve the quality of settlements around the site of tourism and industry. To support this, the Ministry not only strengthen infrastructure PUPR connectivity, but also water resources infrastructure and settlement.

Industrial development and tourism grew stronger with the support of the policy in the Ministry of transportation and Ministry of Agrarian and Spatial. Ministry of transportation support the construction airports and ports for easy access to the tourist sites and industry. On the other hand, the Ministry of Agrarian and Space continue to improve certainty related spatial plan and the process of acquiring land to encourage increased investment in the industrial sector and tourism.

Coordination meetings produced a number of important agreements which will be manifested in the form of a consistent policy and synergize with timely implementation and measurable.

- Encourage the development of an integrated industry in the domestic and global supply chains coupled structuring strategies the development of the competitiveness of the industry. The focus of development is on the increase in efficiency and productivity through the acceleration of infrastructure development including logistics and facilitation of energy, fiscal, investment climate and access to financing for strengthening the structure of the industry, the development of the region industry, the preparation of plans for defensive and offensive access products-featured products, as well as the preparation of competent industry workforce.

- Related to the acceleration of the development of logistics, the Government is committed to completing the completion of the construction of the motorway access Semarang Solo, the music back on the railway line towards Tanjung Mas, and speed up the completion of the construction of Tanjung Adikarto. The Government will fine-tune the related land use regulation owned government agencies for the benefit of infrastructure development.

- For the development of the industrial park, the Government will optimize the development of industrial zones in Central Java in Kendal, Demak, Boyolali, Sukoharjo, and coral Later. Specifically in the region of DKI Jakarta, local Government will reorganize industrial development by diverting heavy industry to the outside area of Jakarta in order to encourage new economic growth center. Meanwhile, Jakarta will focus on the development of creative industries and services.

- Accelerating the development of tourism agriculture in 10 destination priority, including the development of tourism "Great Java" which consists of "Great", "Great Jakarta Bandung", "Great Yogyakarta Central Java", and "Great Surabaya." Various programs will be implemented for the development of tourism destinations, an increase of tourists abroad, as well as the Malay Archipelago and institutional.

- Accelerate the infrastructure development needed to boost industrial competitiveness and access to tourist destinations, 
especially roads, ports and airports. In this regard, priority was given to the development of infrastructure to support an industrial area and tourism destinations, including the airport capacity enhancement and/or construction of a new airport that is now no longer adequate as the entrance relationship or national tourism.

- The Government gives special attention to the measures required to speed up the construction of the airport and its supporting transportation Tags. These include supporting transport access roads and trains from Yogyakarta to Tags. In addition, the Government will speed up the process of land acquisition for construction of The Southern Cross (JJLS). To support this, the local government is committed to supporting the process of the provision of land and ease licensing, as well as strengthen the synergy between regions or between regions.

- Bank Indonesia is committed to maintaining macroeconomic stability and financial system. In addition, to support the agenda of priorities and the national tourism industry Development Bank Indonesia will encourage the development of utilization of non cash transactions in support of the increased efficiency of transactions, SMALL MEDIUM ENTERPRISES industry cluster development through strengthening capacity against access financing, as well as the provision of a wide range of studies, information, and data.

\section{CONCLUSION}

Indonesia has the appeal, thus becoming tourist destinations of the entire population of various countries in the world, in spite of the Government and all the elements of the elements be it stake holder community, private, need to cooperate in providing optimal service so travelers feel comfortable, secure in Indonesia, as a sociological existence of society Indonesia truly has become the attraction for tourism, both with a wealth of customs and traditions, art creations in various facets of his life also cache environment and its relative quite rich and become Essentials.

\section{REFERENCES}

[1]. Bertha Silvia Sutejo (2006), "Internet Marketing: concepts and issues New marketing world", Journal of management, vol. 6, no. 1, Nov. 2006.

[2]. Eko Nurmianto et al (2004), "the formulation of Partnership Strategies Using SWOT and AHP Methods (case study on PT INKA Partnerships with small and medium Industries in the area of Residency of Madiun)", Journal of industrial engineering vol. 6, no. 1, June 2004 Francis Butle (1996), " Relationship Marketing Theory and Practice ", British Library Cataloguing in Publication Data, London: Paul Chapman Publishing Ltd.

[3]. Hatane Semuel (2007), "the influence of Stimulus Media ads, pocket money, age, and Gender Against a tendency Impulse Purchase Behavior (a case study of the tourism Products)", Journal of marketing management, vol. 2, no. 1, April 2007
[4]. Jeffrey e. Lewin and Wesley j. Johnston (1997), "Relationship Marketing A Case Study", Relationship Marketing Theory, Journal of Business Research 39, 23-31 (1997), Jagadish n. Sheth and Parvatiyar Atul (2002), "the Evolving Relationship Marketing into a Discipline" , Journal of Relationship Marketing, vol. 1 (1) 2002.

[5]. Philip Kotler (2002), "Marketing Management Millenium Edition", University of Phoenix, Boston: Pearson Custom Publishing 2002.

[6]. Stephen 1. Vargo and Lusch Robert f. (2004), "Evolving to a New Dominant Logic for Marketing", Journal of Marketing, vol. 68 (January 2004). 